\title{
Management Evaluation Of Income Generating Projects Of Sucs In Eastern Visayas, Philippines
}

\author{
NELIA M. ADORA ${ }^{1}$, CHERRY I. ULTRA ${ }^{2}$ \\ ${ }^{1}$ College of Education, University of Easter Philippines, Philippines \\ ${ }^{2}$ Office of the University President, University of Eastern Philippines \\ 1,2 University Research and Development Services, University of Eastern Philippines, University Town, Catarman, Northern \\ Samar 6400 \\ ${ }^{1}$ neliamadora@gmail.com
}

\begin{abstract}
Liberating the SUCs from limited resources is a challenge they face; otherwise excellence in the areas of instruction, research, extension, and production will be at stake. As such, they need to establish income generating projects or IGPs. A descriptive study evaluated the Income Generating Projects (IGPs) of the State Universities and Colleges (SUCs) in Region VIII. The detailed assessment of the IGPs of the SUCs focused on the profile of the IGP administrators and employees; profile of IGPs of SUCs in Region VIII; status of the IGPs of SUCs in region VIII as perceived by the IGP administrators, employees and clients in terms of setting up an IGP programs, organizational structure, operation performance measurement, profit sharing and accounting. All aspects of operations,namely, setting up an IGP program, organizational structure, operations, performance measurement, profit sharing and accounting, were rated as "often" as perceived and were found to have highly significant differences of perceptions. It was recommended that administrators and the entire management of the different SUCs in Region should strengthen the operations of IGPs through giving it as a priority and through conforming to the standards set in the proposed IGP Manual.
\end{abstract}

Keywords

Income Generating Project, Eastern Visayas, Performance Management

Article Received: 10 August 2020, Revised: 25 October 2020, Accepted: 18 November 2020

\section{Introduction}

The Higher Education Modernization Act of 1997 or RA 8292 grants corporate powers to the Governing Boards of State Universities and Colleges (SUCs) to broaden not just the resource base of the SUCs but also, provide individual SUCs with greater discretion in the utilization of the income they generate. Specifically, RA 8292 allows SUCs (i) to retain any income that they generate from tuition fees and other charges, the operation of auxiliary services and income generating projects, and to utilize said income for instruction, research, extension and other SUCs programs in accordance with a budget approved by the Board of Regents/ Trustees (BOR/T), (ii) to enter into joint ventures with business and industry for the profitable development and management of their economic assets, the proceeds of which can be used for the SUCs development, and (iii) to privatize, when advantageous to the SUC, management and non-academic services such as, health, building/ grounds maintenance and the like. In effect, these powers will allow SUCs to be more fiscally self-reliant by mobilizing increased funding support from all stakeholders (government, students, and private sectors) to augment budgetary support coming from national government appropriations. Moreover, it is envisioned that the delegation of resource allocation authority to the respective BOR/T of SUCs would result in the improvement in the delivery of their core mandates: instruction, research and extension (Manasan and Revilla, 2015).

On the other hand, it is the policy of the State that the national government shall contribute to the financial support of higher education programs pursuant to the goals of education as declared in the Constitution. Towards this end, the government shall adopt measures to broaden access to education through financial assistance and other forms of incentives to schools, teachers, and students.

As such, liberating the SUCs from limited resources is a challenge they face; otherwise excellence in the areas of instruction, research, extension, and production will be at stake. These substantial constraints caused the inception of engaging the SUCs into entrepreneurship. A higher education may engage in any auxiliary enterprise to generate income primarily to finance their educational operations and/or to reduce the need to increase students' fees. Entrepreneurship is the process of creating something different value by devoting the necessary time and effort, assuming the accompanying financial, psychic, and social risk and receiving the resulting rewards of monetary and personal satisfaction (Asor, 2009). The entrepreneurial program through income generating activities of the SUCs can partly resolve the limited infrastructure, facilities and financial resources.

In general, income generating projects (IGPs) include all enterprises or activities established and operated not only to generate profits, but also, to contribute to the social and economic benefits to the community, in particular and to the country's economy, in general. With IGPs, additional resources can be made available to substantiate the financial requirements for the unfunded programs and projects of the school. The school can maximize the involvement of its faculty and staff who are hardworking and talented people, making up a rich human resource that is still untapped due to limited opportunities. Providing them with good working environment to further enhance their camaraderie with peers, while being productive and earn incentive at the same time is a wholesome motivation. IGPs can also serve as 
buffer for instructional laboratories providing a good ground of learning in school. Likewise, their experiences will equip them with the needed skills and technical know-how which can empower themselves to engage in entrepreneurial activity in the future. Also, IGPs can pursue the development and growth of small and medium enterprise in the community when involved as partners of the programs. It helps a lot in rejuvenating economic activity as it creates opportunities and jobs. Apparently, to revisit the concept of entrepreneurial activities in the context of nation building and service of the people, SUCs can help the government retrench its budget. Along this insight, this study has assessed the IGPs of the SUCs for them to grow within the ambit of effective and efficient management as prescribed by the IGP Manual of the Region.

\section{Methodology}

The study employed descriptive assessment as method in pursuing the problems posed in the study. The research revolved around the ten (10) SUCs of Region VIII which are located in Samar and Leyte. The identified respondents of the study were IGP administrators, employees, and clients of the ten (10) state universities and colleges (SUCs) in Region VIII. There were forty- three (43) administrators, eighty (80) employees, one hundred fifty (150) clients of IGPs products. The total number of respondents was 273 . The study made use of two (2) sets of survey questionnaires which were answered by the respondents. The instrument used in this study was a researcher-made questionnaire. In developing the instrument, various reading materials were resorted to by the researcher in order to come up with a comprehensive set of items in the questionnaire.

\section{Results And Discussion}

All of the IGPs in the SUCs of Eastern Visayashave been in existence for quite some time already. This is a normal scenario considering that each University needs to augment their source of income from various income generating projects so as to subsidize, if not fund some expenses of the University as well as, provide some benefits of the personnel to be taken from income. These findings imply that each of SUCs in Region VIII employ different number of personnel to operate its IGP depending on the extent of the IGPs operating and the capacity of the University to pay the salaries of the personnel. Number of IGP Projects. There is no uniform number of projects for each SUC. Each SUC has to create and establish its own income generating project and presumably, the better and more resourceful the management is, the more IGPs are established. Amount of Revolving Fund. The maximum amount that the administration could allocate for Revolving Fund is only up to $1,000,000$ considering also the limited budget of the University. Since most Universities operate only on a meager capital, it follows that IGP management could not also initiate big or higher IGPs that require higher capitalization. Annual Income. It implies that annual income varies depending on the number of IGPs the SUC is operating. It implies that annual income varies depending on the number of IGPs the SUC is operating and the kind of project that the SUC has. However, it can also be gleaned from the table that there were SUCs that earn very minimal incomes while some others were really doing well with their IGPs.

The administrators, most especially, possess very competent knowledge in analyzing the cost of the project, beneficiaries, opportunity cost, and income beneficiaries of any IGP that was to be established. They were also good in determining the sustainability of the project, the technology requirements, marketing, and availability of resources needed for an IGP to operate well (table 1).

Table 1. Means and Standard Deviations on the Perceived

Status of the IGPs of State Universities and Colleges in

Eastern Visayas in Terms of Setting up an IGP Program

\begin{tabular}{|c|c|c|}
\hline \multirow[t]{2}{*}{ Conditions } & \multicolumn{2}{|c|}{ Overall } \\
\hline & Mean & SD \\
\hline \multicolumn{3}{|l|}{ Quantitative Analysis } \\
\hline a.Cost of the project & 4.27 & 0.665 \\
\hline b. Cost to beneficiaries & 4.14 & 0.795 \\
\hline c.Opportunity cost & 4.10 & 0.834 \\
\hline d.Income to beneficiaries & 4.09 & 0.884 \\
\hline \multicolumn{3}{|l|}{ Qualitative Analysis } \\
\hline a.Sustainability of the Project & 4.30 & 0.669 \\
\hline \multicolumn{3}{|l|}{ b.Technology Requirements } \\
\hline EAvailability of service provider & 4.18 & 0.738 \\
\hline $\begin{array}{l}\text { ZAbility of the participants to do the } \\
\text { required tasks/skills }\end{array}$ & 4.21 & 0.720 \\
\hline \multicolumn{3}{|l|}{ c.Marketing } \\
\hline EFrequency of needs of the products & 4.23 & 0.719 \\
\hline EExisting price or cost of product & 4.17 & 0.774 \\
\hline $\begin{array}{l}\text { ZCustomer location and their level of } \\
\text { income }\end{array}$ & 4.15 & 0.725 \\
\hline ECompetitors-their strength and weakness & 4.10 & 0.796 \\
\hline ESource of raw materials & 4.14 & 0.799 \\
\hline EPolicies on selling products & 4.12 & 0.834 \\
\hline \multicolumn{3}{|l|}{ d.Availability of res ources } \\
\hline $\begin{array}{l}\text { DResources requires in the IGP are } \\
\text { readily available }\end{array}$ & 4.22 & 0.728 \\
\hline $\begin{array}{l}\text { DResources are not affected by seasonal } \\
\text { weather condition }\end{array}$ & 4.05 & 0.791 \\
\hline EPrices of these inputs do not fluctuate & 4.05 & 0.818 \\
\hline OVERALL & 4.16 & 0.572 \\
\hline
\end{tabular}

Table 2 shows that the personnel always observed the PASUC manual IGP guidelines in the IGPs operation and financial management control system. This implies further that the IGPs personnel were compliant in securing money derived from IGP operations and using it properly and in observing protocols and ethical values so that personnel perform their jobs within the bounds of the law, most particularly when it comes to financial management, accountability, and control activities.

Table 2.Terms of Operations Management and Financial Management and Control System of the IGPs of State Universities and Colleges in Eastern Visayas 


\begin{tabular}{|c|c|c|}
\hline \multirow{2}{*}{ Conditions } & \multicolumn{2}{|c|}{ Overall } \\
\hline & Mean & SD \\
\hline \multicolumn{3}{|l|}{ Operations Management } \\
\hline 9.Provides Flexibility To The Organization & 4.46 & 2.463 \\
\hline b.Can Free Up Staff Time On SmallerProgram-Related & 4.29 & 0.804 \\
\hline $\begin{array}{l}\text { c. Increase the likelihood that organization will generate } \\
\text { net income, which can help improve an organization's } \\
\text { balance sheet }\end{array}$ & 4.28 & 0.788 \\
\hline d.Allows Not Only "React To Change But Anticipate Them" & 4.22 & 0.852 \\
\hline \multicolumn{3}{|l|}{ Financial Management and Control System } \\
\hline \multicolumn{3}{|l|}{ 9.Commitment For Integrity And EthicalValues } \\
\hline $\begin{array}{l}\text { Internal regulations procedures are in compliance with } \\
\text { relevant laws }\end{array}$ & 4.40 & 0.776 \\
\hline ECode of conduct in the organization & 4.39 & 0.761 \\
\hline $\begin{array}{l}\text {-Procedures for reporting the violation of rules on the } \\
\text { ethics }\end{array}$ & 4.30 & 0.812 \\
\hline $\begin{array}{l}\text {-Administrative actions are undertaken for administrative } \\
\text { cases }\end{array}$ & 4.30 & 0.781 \\
\hline \multicolumn{3}{|l|}{ b.Implementation of Accountability } \\
\hline $\begin{array}{l}\text {-1Meetings are conductedon issues relating to fiscal } \\
\text { management and control }\end{array}$ & 4.34 & 0.747 \\
\hline $\begin{array}{l}\text {-Personnel are visited in their working place by } \\
\text { concerned personnelheads }\end{array}$ & 4.34 & 0.765 \\
\hline EConduct of regular meeting & 4.29 & 0.768 \\
\hline $\begin{array}{l}\text { - Managers have the authority of the budget management of } \\
\text { their projects }\end{array}$ & 4.30 & 0.746 \\
\hline $\begin{array}{l}\text {-Written policies on the delegation of duties andits } \\
\text { documentation }\end{array}$ & 4.28 & 0.788 \\
\hline \multicolumn{3}{|l|}{ c.ControlActivities } \\
\hline $\begin{array}{l}\text {-Detailed internal policies rules/ instructions describing } \\
\text { operational work procedures }\end{array}$ & 4.34 & 0.742 \\
\hline IPreparation and execution of financial annugl budget plan & 4.36 & 0.750 \\
\hline Ekeeping and recording of accounting transactions & 4.38 & 0.767 \\
\hline d.Safeguard, use and archive of documents & 4.38 & 0.719 \\
\hline $\begin{array}{l}\text { e.Monitoring|and compliance of employees with the } \\
\text { segregation of dutes }\end{array}$ & 4.37 & 0.741 \\
\hline $\begin{array}{l}\text { OVERALL } \\
\end{array}$ & 4.33 & 0.610 \\
\hline
\end{tabular}

It can be inferred from these results that generally, the IGPs of SUCs were compliant of the IGP Manual and have rigidly observed the many processes involved in IGP operations starting from goal setting, setting of the program, establishing a sound organizational structure, operations, performance measurements, profit sharing, and accounting. However, there were times when the administrators felt that profit sharing was not really consistent with the mandates in the manual and while on the part of the clients, they were seemed so satisfied with the way IGPs have operated.

\section{Conclusions}

Despite of the age of the respondents which were already mature, most of them were still novice in the field of IGP operations. All of the IGPs have already gained a considerable number of years in operation. Yet, their capital investments remained low and as such, income was also not very significant. SUCs have varying profiles from number of personnel, investment or capitalization, income and all these were dependent on how the respective administrations gave priority to the IGP as a major component of the University. The respondents have perceived all aspects of the operations of IGP to be high and performing well.

All projects/IGPs that helped in generating additional income for school were included most of the time in the profit sharing and they income derived from IGP operations contributed somehow to the resources of the University necessary in augmenting the financial resources of the same. Responses of the respondents showed that they were consistent in saying that oftentimes all of the aspects of IGP operations were observed and/or complied with by the IGP program vis-à-vis IGP Manual. The highly significant differences in all of the aspects imply that administrators, employees, and clients have varying levels of rating when it comes to IGP operations based on how they perceived them to be. Nevertheless, all of the three groups of respondents have maintained good ratings in all aspects.

Despite of the good or high ratings on the status of IGP of SUCs in Region VIII, there were still some problems encountered and most of which were finance or budget related. No personal factors were involved in the operations of the IGPs. Employees and administrators were consistent in observing IGPs

\section{References}

[1] Asor, Winefreda T. (2009). Entrepreneurship in the Philippine Setting, Rex Book Store, Manila.

[2] Malate, Renato F. (2009). Corporatization of State Universities and Colleges: Impact on Higher Education. The Threshold, Vol. 4, 82 .

[3] Manual of Operations for Income Generating Projects of State Universities and Colleges in Region VIII, (2001), Tacloban City.

[4] Manasan, Rosario G., Ma. Laarni D. Revilla (2015). Assessment of Sources and Utilization of Funding of State Universities and Colleges, Philippine Institute for Development Studies, Department of Budget and Management.

[5] Republic Act No. 8292 (1997). An Act Providing for the Uniform Composition and Powers of the Governing Boards, the Manner of Appointment and term of Office of the President of Chartered State Universities and Colleges.

[6] Revised Administrative Code. 2005 Revised and Enlarged Edition, Updated by

[7] Nolledo, S. Mercedita, National Book Store, Manila.

[8] Western Mindanao State University (2009). Coconut Sugar Production as an IGP of Western Mindanao State University, College of Agriculture. 